\title{
Characterization of gastrin amidation in the rat and porcine antrum: comparison with the pituitary
}

\author{
Chris J. Dickinson ${ }^{1}$ and Tadataka Yamada ${ }^{2}$ \\ Departments of Pediatrics ${ }^{1}$ and Internal Medicine ${ }^{2}$ University of Michigan Medical Center Ann Arbor, MI \\ (U.S.A.)
}

(Received 13 September 1989; revised version received and accepted 18 January 1990)

Key words: Peptide $\alpha$-amidating enzyme; Post-translational processing; Gastrin

\section{Summary}

The formation of biologically active gastrin from glycine-extended processing intermediates occurs via the action of a peptide $\alpha$-amidating enzyme. The observation that gastrin exists primarily as unamidated precursors in the pituitary but as amidated gastrin in the antrum prompted these studies to examine whether the amidating enzymes in the two organs were different in their characteristics. Furthermore, the amidating enzyme in the stomach has not previously been characterized in extensive detail. Amidating activity was quantified by measuring the conversion of Tyr-Gly-Trp-Met-Asp-Phe-Gly (glycine-extended hexagastrin) to Tyr-Gly-Trp-Met-Asp-Phe- $\mathrm{NH}_{2}$ (amidated hexagastrin) by radioimmunoassay. The activity of the antral enzyme in both the rat and hog had a similar apparent molecular weight $(45,000-60,000)$, cofactor requirements (copper, ascorbic acid, and catalase), pH optima $(5.5-8.5)$, and $K_{\mathrm{m}}(12 \mu \mathrm{M})$ as the pituitary enzyme. These data suggest that antral and pituitary peptide $\alpha$-amidating enzymes are the same enzyme, thus it is unlikely that differences in amidating enzymes can account for the observed differences in the tissue specific processing of gastrin.

\section{Introduction}

The structure of gastrin is similar to numerous other polypeptides of the brain and gut, in that its carboxyl-terminal amino acid is amidated [1]. As with most amidated

Correspondence: C.J. Dickinson, Pediatric Gastroenterology, C.S. Mott Children's Hospital, C6105 MIB, Box 0800, Ann Arbor, MI 48109, U.S.A. 
peptides, the amide is an absolute requirement for biological activity [2]. The carboxyl terminal phenylalanine of gastrin is extended by glycine in the structure of progastrin [3]. Using region-specific antisera, glycine-extended progastrin processing intermediates have been identified in antral G-cells as the immediate precursors of amidated gastrin [4]. However, there are apparent tissue-specific differences in the posttranslational processing of gastrin in that pituitary gastrins exist mainly as large unamidated gastrin precursors while antral gastrin is mainly fully processed, amidated G-17 [5,6]. The peptide $\alpha$-amidating enzyme has been extensively characterized in the pituitary and is believed to be responsible for the amidation of gastrin [7-10]. In the present studies, we sought to characterize the amidation of gastrin in the antrum and to compare it to that found in the pituitary to determine if differences in antral amidating enzyme(s) could explain the tissue-specific differences in the post-translational processing of gastrin.

\section{Materials and Methods}

\section{Preparation of tissue extracts}

Adult male Sprague-Dawley rats (250-300 g) were decapitated and their whole pituitaries and stomachs removed. The stomachs were incised, rinsed in $0.9 \% \mathrm{NaCl}$, and the antral mucosa carefully scraped with a scalpel. Rat antral and pituitary tissues were sonicated in cold $50 \mathrm{mM}$ Tris $\mathrm{HCl}\left(\mathrm{pH} \mathrm{7.0)}\right.$ and frozen at $-70^{\circ} \mathrm{C}$. Frozen hog pituitaries purchased from Pel-Freeze Biologicals (Rogers, AR) and hog antra obtained from a local slaughterhouse were homogenized in cold $50 \mathrm{mM}$ Tris $\mathrm{HCl}(\mathrm{pH} 7.0)$ using a Polytron homogenizer and frozen at $-70^{\circ} \mathrm{C}$. The sonicates and homogenates were subjected to three cycles of freeze-thawing to lyse secretory vesicles. The rat tissues were centrifuged at $40,000 \mathrm{~g}$ for $30 \mathrm{~min}$ and the hog tissues at $80,000 \mathrm{~g}$ for $60 \mathrm{~min}$ in a Beckman Type 40 fixed angle rotor at $4^{\circ} \mathrm{C}$. In order to separate the intrinsic amidated gastrin and gastrin precursors from amidating enzyme, the supernatants were partially purified on a $2.5 \times 120 \mathrm{~cm}$ column of Sephadex G-100 (Pharmacia, Piscataway, NJ), eluted with $50 \mathrm{mM}$ Tris $\mathrm{HCl}(\mathrm{pH} \mathrm{7.0)}$, and $9 \mathrm{ml}$ fractions were collected.

\section{Enzyme assays}

To assay for amidating enzyme activity, the following peptides were synthesized by Peninsula Laboratories, Belmont, CA: Tyr-Gly-Trp-Met-Asp-Phe- $\mathrm{NH}_{2}$ (G6) and Tyr-Gly-Trp-Met-Asp-Phe-Gly (G6-Gly). G6 corresponds to the amidated carboxylterminal hexapeptide of gastrin and G6-Gly corresponds to deamidated G6 extended by glycine. Amidating enzyme activity was quantified by measuring the generation of G6 by radioimmunoassay, utilizing G6-Gly as a substrate. G6 can be measured accurately by a standard gastrin radioimmunoassay using antibody 5135 (kindly provided by $\mathbf{R}$. Rosenquist) that is specific for the amidated carboxyl terminus of gastrin and cross-reacts with G6-gly less than $0.05 \%$ (Fig. 1). Aliquots (100-500 $\mu$ l) of the eluted column fractions were incubated at $37^{\circ} \mathrm{C}$ with G6-gly (50 pmol), cupric sulfate $\left(10^{-6} \mathrm{M}\right)$, ascorbic acid $\left(10^{-3} \mathrm{M}\right)$, and catalase $(100 \mu \mathrm{g} / \mathrm{ml}$, Sigma $)$ at $\mathrm{pH} 7.0$ for 3-5 h in a final volume of $800 \mu 1$. Control column samples were always run in parallel without 


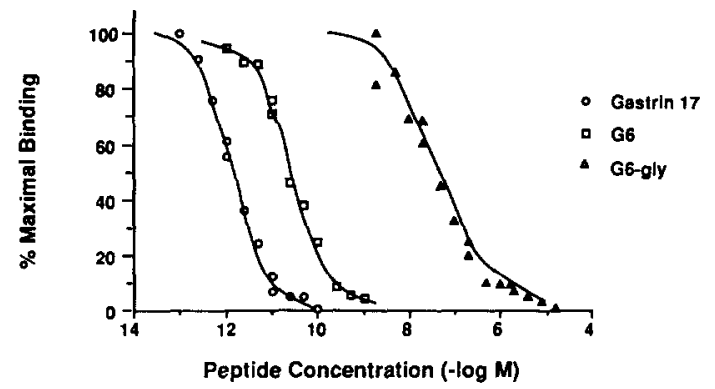

Fig. 1. Crossreactivity of gastrin $17(0)$, hexagastrin (G6, $\square$ ), and glycine-extended hexagastrin (G6-Gly, $\triangle$ ) with antibody 5135 utilizing ${ }^{125} \mathrm{I}-\mathrm{Leu}^{15}$-gastrin-17 as label.

the substrate G6-Gly added and peptide $\alpha$-amidating enzyme-containing fractions were then pooled for further experiments. To obtain an accurate measure of reaction velocity for kinetic studies the crossreactivity of $\mathrm{G} 6$ was noted to be $4 \%$ in the gastrin radioimmunoassay when using ${ }^{125} \mathrm{I}_{\text {-Leu }}{ }^{15}$-gastrin-17 as label and unlabeled Met $^{15}$-gastrin-17 as standard (Fig. 1). G6-Gly was quantified using antibody 8237 as previously described [11].

The pooled amidation enzyme containing fractions after Sephadex chromatography were used to determine the optimal concentrations of $\mathrm{Cu}^{2+}$, ascorbic acid and catalase which were used in subsequent $\mathrm{pH}$ and kinetic experiments. In addition to the cofactors the following $150 \mathrm{mM}$ buffers were added to the reactions to adjust the $\mathrm{pH}$ as follows: acetate (pH 4.0 and 4.5); Mes (pH 5.0, 5.5, 6.0 and 6.5); and Tris (pH 7.0, 7.5, 8.0, 8.5 and 9.0). Since maximal reaction velocities often varied between preparations and between pituitary and antral tissues, results were expressed as percentage of maximal velocity in order to permit comparisons between preparations and tissues. Kinetic parameters were determined with optimal amounts of cofactors at $\mathrm{pH} 7.0$ and with varying concentrations of substrate $(0.5-100 \mu \mathrm{M})$. The kinetic reactions were performed in a final volume of $100 \mu \mathrm{l}$ at $37^{\circ} \mathrm{C}$ for 3-5 $\mathrm{h}$ and stopped by the addition of $100 \mu 1$ of 0.01 M EDTA. $K_{\mathrm{m}}$ and $V_{\max }$ were derived using Eadie-Hofstee plots and the best-fit equations were determined by the unweighted least-squares method. Protein concentrations for kinetic experiments were determined using the Bradford method (Bio-Rad, Richmond, $\mathrm{CA}$ ) and the velocity results recorded as pmol G6 produced/mg protein/h. Samples for kinetic and $\mathrm{pH}$ experiments were assayed in duplicate at each $\mathrm{pH} /$ substrate concentration. All experiments were performed at least three times in the four tissues examined.

\section{Results}

Amidation activity was completely inhibited by boiling the protein (enzyme) containing fractions for 15 min prior to incubation and no activity was observed in the absence of protein at any concentration of copper and/or ascorbic acid tested. These data confirm the enzymatic nature of the amidation process. To ensure that substantial degradation of either substrate (G6-Gly) or product (G6) did not occur, samples were 


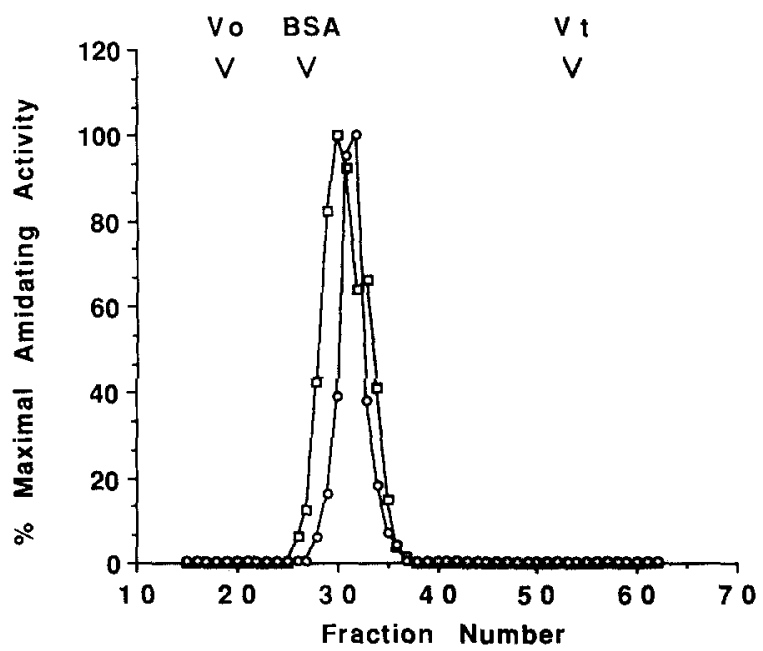

Fig. 2. Sephadex G-100 elution profile of hog pituitary $(O)$ and antral $(\square)$ amidating activity. $V_{0}$ : void volume; $V_{t}$ : salt peak; and BSA: elution position of bovine serum albumin. Similar elution profiles were obtained for the rat pituitary and antrum.
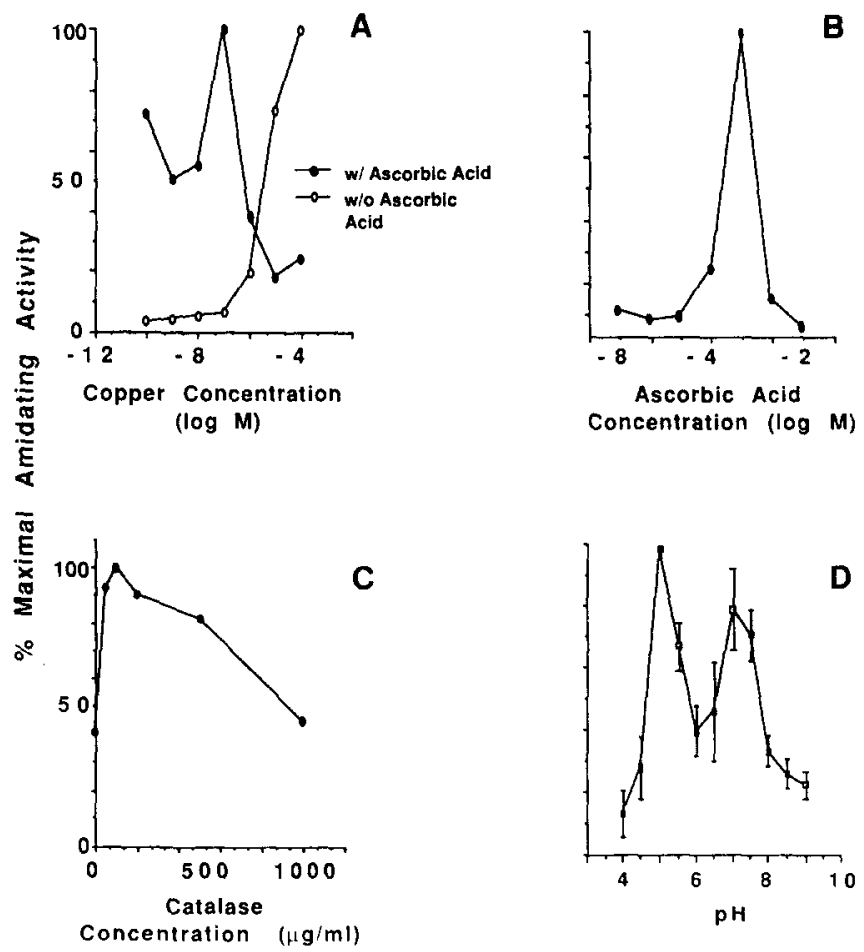

Fig. 3. Panel A demonstrates the effect of copper on amidating activity in the presence $(O)$ and absence (O) of $10^{-3} \mathrm{M}$ ascorbic acid and $100 \mu \mathrm{g} / \mathrm{ml}$ catalase. Panel B shows the effect of ascorbic acid on enzyme activity in the presence of $10^{-6} \mathrm{M} \mathrm{Cu}^{2+}$ and $100 \mu \mathrm{g} / \mathrm{ml}$ catalase. Panel $\mathrm{C}$ shows the effect of catalase on amidating activity in the presence of $10^{-6} \mathrm{M} \mathrm{Cu}^{2+}$ and $10^{-3} \mathrm{M}$ ascorbic acid. Panel $\mathrm{D}$ demonstrates the effect of $\mathrm{pH}$ on enzyme activity under optimal conditions (see text) for the hog pituitary. Error bars represent \pm S.E.M. All experiments were performed at $\mathrm{pH} 7.0$ unless otherwise indicated. 
also assayed for G6-Gly by radioimmunoassay using antibody 8237 which did not crossreact with G6 to any appreciable degree [11]. The recovered sum of G6-Gly and G6 was always greater than $85 \%$ of the initial G6-Gly immunoreactivity. Amidating activity was linear with the amount of protein added and with time over the $3-5 \mathrm{~h}$ incubation period (data not shown).

Amidation enzyme activity eluted from the Sephadex G-100 column in a broad peak with an apparent molecular weight of $45,000-60,000$ in both the pituitary and antral tissues studied (Fig. 2). The separation of amidation enzyme activity from intrinsic gastrin and gastrin precursors was efficient in that there was no gastrin or G6-Gly immunoreactivity in the enzyme containing fractions.

Amidating activity was then characterized in the pooled fractions and could be inhibited completely by the divalent cation chelators, diethyldithiocarbamate and EDTA. $\mathrm{Cu}^{2+}$ increased the reaction velocity, although the optimal concentration $\left(10^{-6} \mathrm{M}\right)$ varied between tissues and preparations in the presence of ascorbic acid (Fig. 3A). $\mathrm{Cu}^{+2}$ also stimulated activity in the absence of ascorbic acid, but the optimal concentration $\left(10^{-4} \mathrm{M}\right.$ ) was higher than in the presence of ascorbic acid (Fig. 3A). Although ascorbic acid increased the reaction velocity at optimal concentrations $\left(10^{-3} \mathrm{M}\right)$, it also inhibited the reaction at higher concentrations and amidating activity was noted in the absence of added ascorbic acid (Fig. 3B). Catalase increased the reaction velocity (optimal concentration $100 \mu \mathrm{g} / \mathrm{ml}$ ) in the presence of ascorbic acid, but was also inhibitory at higher concentrations (Fig. 3C). Optimal cofactor concentrations were similar in all four tissues studied and were used for kinetic and $\mathrm{pH}$ experiments. The amidating enzyme was active across a wide $\mathrm{pH}$ range with two peaks of optimal activity noted at pH 5.5 and 7.0 in the rat and hog pituitary and rat antrum (Fig. 3D). The hog antrum exhibited consistently high levels of activity from pH 5.0 to 9.0 (data not shown).

Amidating activity obeyed Michaelis-Menten kinetics (Fig. 4) and no differences in $K_{\mathrm{m}}$ were observed in any of the four tissues studied although the $V_{\max }$ was higher in the pituitary than the antrum when results were expressed as pmol G6 produced/mg protein/h (Table I).

TABLE I

Michaelis-Menten constants and maximum reaction velocity values in hog and rat pituitary and antrum

\begin{tabular}{lcc}
\hline & $\begin{array}{l}K_{\mathrm{m}} \\
(\mu \mathrm{M})\end{array}$ & $\begin{array}{l}V_{\max } \\
(\mathrm{pmol} \mathrm{G6} \text { produced/mg protein/h) }\end{array}$ \\
\hline Rat antrum & 10.2 & 45 \\
Hog antrum & 15.0 & 63 \\
Rat pituitary & 7.8 & 122 \\
Hog pituitary & 14.3 & 204
\end{tabular}




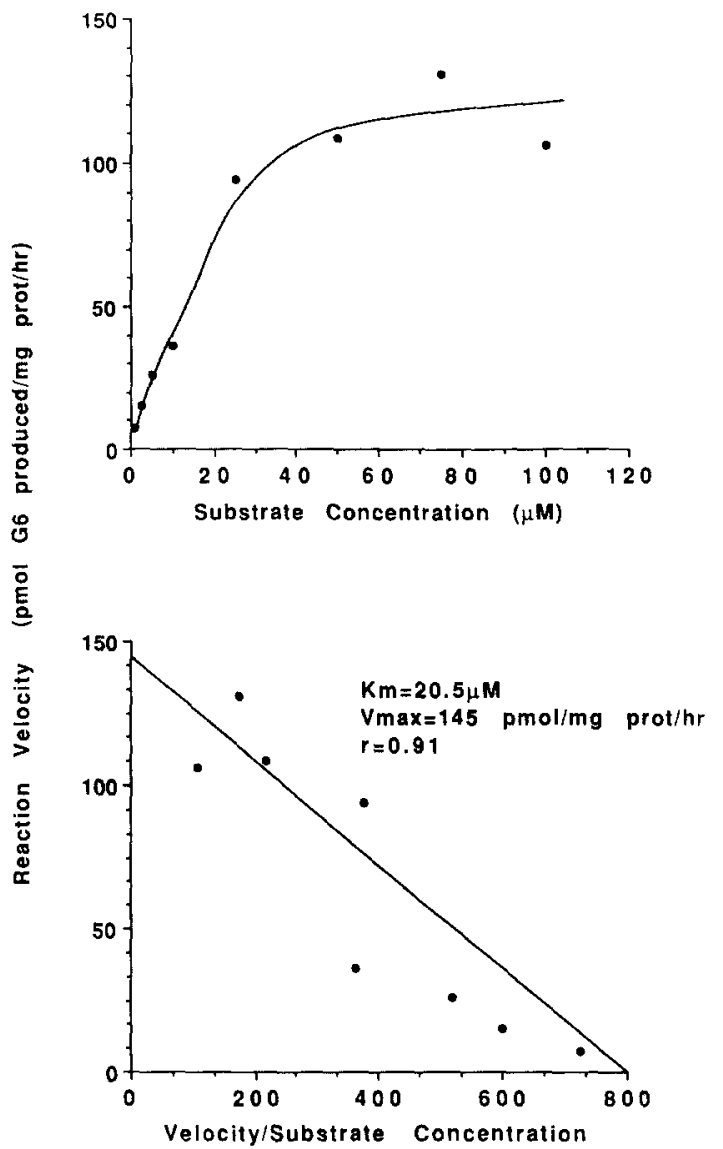

Fig. 4. Typical plot of substrate concentration versus reaction velocity for the hog pituitary (upper panel) and the subsequent Eadie-Hofstee plot (lower panel) from which the $K_{\mathrm{m}}$ and $V_{\max }$ were derived. Similar plots were obtained in all four tissues examined $(n \geq 3)$.

\section{Discussion}

The crucial importance of the amidation reaction for the activation of gastrin has been established in studies demonstrating the markedly reduced potency of G6-Gly in biological assays when compared to gastrin $[12,13]$. Although an enzyme capable of conducting this reaction in the pituitary has been extensively studied, the enzyme in the gastric antrum has not been characterized. Furthermore, since antral gastrin is mainly amidated and fully processed G-17 while in the pituitary gastrin exists mainly as large unamidated precursors $[5,6]$, we hypothesized that there may be tissue specific differences in the peptide $\alpha$-amidating enzyme which could account for the observed differences in gastrin post-translational processing. Our studies indicate that antral amidating activity is quite similar to pituitary amidating activity in both the hog and rat. The antral enzyme eluted from Sephadex G-100 in the same broad peak (molecular weight: $45,000-60,000$ ) as that found in the pituitary, suggesting that the antral and 
pituitary enzymes were of similar molecular weight. This is consistent with the approximate molecular weight found by other investigators in a variety of tissues $[7,9,10,14]$, although the antral enzyme has been reported by one investigator [15] to be much larger $(200,000)$. Antral and pituitary amidating enzymes were also quite similar with respect to their cofactor optima. As with the pituitary enzyme, antral amidating activity was enhanced by the presence of ascorbic acid and catalase, although both substances could inhibit activity at higher concentrations. Amidating activity was also noted in the absence of either ascorbic acid or catalase in all four tissues studied indicating that the requirements of the enzyme for these cofactors was not absolute in our partially purified preparation. In contrast, the activity of both the pituitary and antral enzymes was completely inhibited by EDTA and diethyldithiocarbamate, suggesting that a divalent cation was essential for optimal activity. Indeed, optimal concentrations of $\mathrm{Cu}^{2+}$ enhanced enzyme activity in all four tissues studied in the presence or absence of ascorbic acid. As noted by others [16], we detected minor differences in the optimal copper concentrations between preparations and tissues. These differences probably do not reflect intrinsic differences between enzymes of the various tissues, but may reflect differences in endogenous enzyme inhibitors, copper chelators encountered in the partial purification process, or changes in the purity of the water used.

Enzyme activity exhibited a broad $\mathrm{pH}$ optimum in all four tissues studied, with two peaks of activity (pH 5.5 and 7.0) in the rat antrum, rat pituitary and the hog pituitary. The hog antrum exhibited amidating activity across a broad $\mathrm{pH}$ range from 5.0 to 9.0 . It is of great interest to note that amidating activity was present at $\mathrm{pH} 5.5$ since it is believed that amidation occurs in the intracytoplasmic secretory vesicle where the $\mathrm{pH}$ is approximately $5.5[17,18]$. On the other hand, amidating activity has been detected in serum and cerebral spinal fluid $[19,20]$ as well, where the $\mathrm{pH}$ optima of 7.0 could provide some level of advantage. Although the finding of two distinct peaks of enzyme activity may reflect two $\mathrm{pH}$ optima of a single enzyme it may also reflect two molecular forms of the enzyme with a similar molecular weight.

Enzyme activity obeyed Michaelis-Menten kinetics in all four tissues studied and the $K_{\mathrm{m}}$ for the gastrin precursor G6-Gly was similar in the pituitary and the antrum suggesting that the antral and pituitary amidating enzymes had the same affinity for G6-Gly under the optimal conditions studied. Furthermore, the $K_{\mathrm{m}}$ for the pituitary enzyme using G6-Gly as a substrate was similar to the published $K_{\mathrm{m}}$ of approximately $9 \mu \mathrm{M}$ for D-Tyr-Val-Gly in the rat anterior pituitary in the presence of ascorbic acid and catalase [21]. When expressed as pmol G6 produced/mg protein/h, the $V_{\max }$ for the pituitary enzyme was greater than that of the antral enzyme. This difference could be accounted for by the presence of less enzyme/mg protein in the antrum than in the pituitary, although an intrinsic difference in the antral and pituitary enzymes cannot be excluded on this basis alone. Previous studies of the amidating enzyme in the pituitary have utilized synthetic tripeptides such as, D-Tyr-Val-Gly or D-Tyr-Phe-Gly [7,8,22], or the TRH precursor, pGlu-His-Pro-Gly [23] as substrates, however for our studies we felt that a natural substrate for the gastric enzyme, G6-Gly would be more appropriate. Moreover, the ability to study the reaction by radioimmunoassay has greatly improved the sensitivity of the enzyme assay. Our studies demonstrate that the amidation of gastrin in the pituitary and antrum is quite similar to the amidation of other 
peptide substrates in the pituitary with respect to cofactor and $\mathrm{pH}$ optima, as well as $K_{\mathrm{m}}$, regardless of the substrate utilized.

It is of note that to measure peptide $\alpha$-amidating activity we utilized for our substrate the synthetic peptide Tyr-Gly-Trp-Met-Asp-Phe-Gly in contrast to the smaller tripeptide substrates used by other investigators $[7,8,22]$. In light of the reported wide distribution of enkephalinase and other endopeptidases which could potentially degrade our substrate $[23,24]$, we were gratified to note that the substrate was stable for $3-5 \mathrm{~h}$ under the conditions of study. We presume that this resulted from the fact that we partially purified our enzyme preparation prior to assaying its activity. Moreover, we utilized a cytosol-derived fraction for our enzyme source instead of the membranous fraction from which endopeptidases are usually extracted [25]. The extraordinary advantage that we gained from the use of our substrate was that the product could be quantified by radioimmunoassay to levels as low as $1 \mathrm{fmol} / \mathrm{ml}$.

In conclusion, we have shown that pituitary and antral amidating activities in the hog and rat are similar with respect to apparent molecular weight, copper and ascorbic acid dependence, enhancement with catalase, $\mathrm{pH}$ optima, and $K_{\mathrm{m}}$. Furthermore, these characteristics are similar or identical to those previously described in the pituitary and thyroid [26] and suggest that the antral amidating enzyme may be the same as pituitary enzyme. It is therefore unlikely that the observed tissue-specific differences in the post-translational processing of gastrin can be explained solely by differences in amidating enzymes, although further studies to elucidate the structure of antral amidating enzyme will be necessary to confirm this hypothesis. Other possible mechanisms for the tissue specific differences in the post-translational processing of gastrin include differences in tissue concentrations of cofactors and differences in the activity of the processing enzymes responsible for generating glycine-extended processing intermediates from progastrin. These possibilities are currently under investigation.

\section{Acknowledgements}

This work was supported by funds from the Michigan Gastrointestinal Peptide Research Center (NIH grant P30 DK-34933) and by National Institutes of Health grants RO1 DK-34306 and F32 DK-07860.

\section{References}

1 Gregory, H., Hardy, P.M., Jones, D.S., Kenner, G.W. and Sheppard, R. C., The Antral Hormone Gastrin, Nature, 204 (1964) 931-933.

2 Rehfeld, J.F., Four basic characteristics of the gastrin-cholecystokinin system, Am. J. Physiol., 240 (1981) G255-G266.

3 Yoo, Y.C., Powell, C.T. and Agarawal, K. L., Molecular cloning and nucleotide sequence of full-length cDNA coding for porcine gastrin, Proc. Natl. Acad. Sci. USA, 79 (1982) 1049-1053.

4 Sugano, K., Aponte, G. and Yamada, T., Identification and characterization of glycine-extended post-translational processing intermediates of progastrin in porcine stomach, J. Biol. Chem., 260 (1985) $11724-11729$. 
5 Rehfeld, J.F. and Larsson, L., Pituitary gastrins: Different processing in corticotrophs and melanotrophs, J. Biol. Chem., 256 (1981) 10426-10429.

6 Rehfeld, J.F., Accumulation of nonamidated preprogastrin and preprocholecystokinin products in porcine pituitary corticotrophs, J. Biol. Chem., 261 (1987) 5841-5847.

7 Bradbury, A.F., Finnie, M. and Smyth, D., Mechanism of C-terminal amide formation by pituitary enzymes, Nature, 298 (1982) 686-688.

8 Eipper, B., Mains, R. and Glembotski, C., Identification in pituitary tissue of a peptide $\alpha$-amidation activity that acts on glycine-extended peptides and requires molecular oxygen, copper, and ascorbic acid, Proc. Natl. Acad. Sci. USA, 80 (1983) 5144-5148.

9 Murthy, A.S.N., Mains, R.E. and Eipper, B.A., Purification and characterization of peptidylglycine $\alpha$-amidating monooxygenase from bovine neurointermediate pituitary, J. Biol. Chem., 261 (1986) 1815-1822.

10 Kizer, J.S., Bateman, R. C., Miller, C. R., Humm, J., Busby, Jr., W.H. and Youngblood, W.W., Purification and characterization of a peptidyl glycine monooxygenase from porcine pituitary, Endocrinology, 118 (1986) 2262-2267.

11 Sugano, K. and Yamada, T., Progastrin-like immunoreactivity in porcine antrum: Identification and characterization with region-specific antisera, Biochem Biophys. Res. Commun., 126 (1985) 72-77.

12 Hilsted, L., Hint, K., Christiansen, J. and Rehfeld, J. F., Neither glycine-extended gastrin nor the 1-13 fragment of gastrin-17 influences gastric acid secretion in humans, Gastroenterology, 94 (1988) 96-102.

13 Matsumoto, M., Park, J., Sugano, K. and Yamada, T., Biological activity of progastrin posttranslational processing intermediates, Am. J. Physiol., 252 (1987) G315-G319.

14 Sakata, J., Mizuno, K. and Matsuo, H., Tissue distribution and characterization of peptide C-terminal $\alpha$-amidating activity in rat, Biochem. Biophys. Res. Commun., 140 (1986) 230-236.

15 Conway, R.G., Tsai, B.S., Butchko, R.F., Bauer, R.F. and Radzialowski, F.M., Peptidyl-glycine $\alpha$-amidation monooxygenases; Comparison of stomach and pituitary enzymes, Fed. Proc., 44 (1985) 4719 (Abstr.).

16 Murthy, A.S.N., Kuetmann, H.T. and Eipper, B.A., Further characterization of peptidylglycine $\alpha$-amidating monooxygenase from bovine neurointermediate pituitary, Mol. Endocrinol., 1 (1987) 290-299.

17 Loh, Y.P., Tam, W.W.H. and Russell, J.T., Measurement of $\Delta \mathrm{pH}$ and membrane potential in secretory vesicles isolated from bovine pituitary intermediate lobe, J. Biol. Chem., 259 (1984) 8238-8245.

18 Russell, J.T. and Holz, R., Measurement of $\Delta \mathrm{pH}$ and membrane potential in isolated neurosecretory vesicles from bovine neurohypophyses, J. Biol. Chem., 256 (1981) 5950-5953.

19 Wand, G. S., Ney, R. L., Baylin, S., Eipper, B. and Mains, R.E., Characterization of a peptide $\alpha$-amidation activity in human plasma and tissues, Metabolism, 34 (1985) 1044-1052.

20 Wand, G. S., Ney, R. L., Mains, R. E. and Eipper, B. A., Characterization of peptide $\alpha$-amidation activity in human cerebrospinal fluid and central nervous system tissue, Neuroendocrinol., 41 (1985) 482-489.

21 Glembotski, C.C., Eipper, B.A. and Mains, R.E., Characterization of a peptide $\alpha$-amidation activity from rat anterior pituitary, J. Biol. Chem., 259 (1984) 6385-6392.

22 Kizer, J.S., Busby, W.H. Jr., Cottle, C. and Youngblood, W.W., Glycine-directed peptide amidation: Presence in rat brain of two enzymes that convert p-Glu-His-Pro-Gly-OH into p-Glu-His-Pro- $\mathrm{NH}_{2}$ (thyrotropin-releasing hormone), Proc. Natl. Acad. Sci. USA, 81 (1984) 3228-3232.

23 Deschodt-Lanckman, M., Koulischer, D., Przedborski, S. and Lauwereys, M., Cholecystokinin octaand tetrapeptide degradation by synaptic membranes. III. Inactivation of CCK- 8 by a phosphoramidonsensitive endopeptidase, Peptides, 5 (1984) 649-51.

24 Power, D. M., Bunnett, N., Turner, A. J. and Dimaline, R., Degradation of endogenous heptadecapetide gastrin by endopeptidase 24.11 in the pig, Am. J. Physiol., 253 (1987) G33-G39.

25 Bunnet, N. W., Turner, A. J., Hryszko, J., Kobayshi, R. and Walsh, J. H., Isolation of endopeptidase-24.11 (EC 3.4.24.11, 'enkephalinase') from the pig stomach. Hydrolysis of substance $P$, gastrin-releasing peptide 10, $\left[\mathrm{Leu}^{5}\right]$ enkephalin, and $\left[\mathrm{Met}^{5}\right]$ enkephalin, Gastroenterology, 95 (1988) 952-957.

26 Bradbury, A.F. and Smyth, D. G., Amide forming enzymes in thyroid and pituitary. In V.J. Hruby and D.H. Rich, Peptides: Structures and Function, Pierce Chemical Co., 1983, pp. 249-252. 